\title{
Pituitary Adenylate Cyclase Activating Polypeptide: A Neuropeptide with Potent Inotropic and Coronary Vasodilatory Effects in Neonatal Pig Hearts
}

\author{
NANCY T. ROSS-ASCUITTO, ROBERT J. ASCUITTO, DAVID RAMAGE, DONALD W. KYDON, \\ DAVID H. COY, AND PHILIP. J. KADOWITZ \\ Tulane University School of Medicine, Department of Pediatrics [N.T.R.-A., R.J.A., D.R., D.W.K.] Section of \\ Cardiology' and Department of Pharmacology [D.H.C., P.J.K.J, New Orleans, Louisiana 70112
}

\begin{abstract}
Cardiac effects of the neuropeptide pituitary adenylate cyclase activating polypeptide (PACAP) have not previously been reported. We investigated the influence of PACAP, vasoactive intestinal polypeptide $(68 \%$ homology with PACAP) and the $\beta$-adrenergic receptor agonist isoproterenol on contractile function and coronary vascular tone in isolated piglet hearts ( 1 to $5 \mathrm{~d}$ of age). Paced (180 beats $/ \mathrm{min}$ ) isovolumically beating hearts underwent retrograde aortic perfusion at constant coronary flow (approximately $3 \mathrm{~mL} \cdot \mathrm{min}^{-1} \cdot \mathrm{g}^{-1}$ ) with an erythrocyte-enriched (hematocrit 15 to $20 \%$ ) solution $\left(37^{\circ} \mathrm{C}\right)$. Agonists were injected into the aortic root of hearts, and the positive (+) and negative $(-)$ changes in maximum rate of change of systolic pressure with respect to time $\left(\mathrm{dP} / \mathrm{dt}_{\max }\right)$ and in coronary perfusion pressure (that reflected alterations in vascular tone) were measured. PACAP $(n=8,0.1$ and 0.5 $\mathrm{nmol}$ ) increased $(+) \mathrm{dP} / \mathrm{dt}_{\max }$ from $944 \pm 59$ to $1519 \pm 206$ $\mathrm{mm} \mathrm{Hg} / \mathrm{s}$ and from $867 \pm 40$ to $2010 \pm 226 \mathrm{~mm} \mathrm{Hg} / \mathrm{s}(p$ $<0.05)$; increased $(-) \mathrm{dP} / \mathrm{dt}_{\max }$ from $1114 \pm 41$ to $1439 \pm$ $95 \mathrm{~mm} \mathrm{Hg}$ and from $999 \pm 37$ to $1668 \pm 145 \mathrm{~mm} \mathrm{Hg} / \mathrm{s}$ $(p<0.05)$; and decreased perfusion pressure from 61.4 \pm 3.1 to $48.9 \pm 2.3 \mathrm{~mm} \mathrm{Hg}$ and from $60.5 \pm 2.4$ to $43.9 \pm$ $2.3 \mathrm{~mm} \mathrm{Hg}(p<0.05)$, respectively. In comparison, vasoactive intestinal polypeptide $(n=6,0.1$ and $0.5 \mathrm{nmol})$ increased (+) $\mathrm{dP} / \mathrm{dt}_{\max }$ from $767 \pm 53$ to $806 \pm 37 \mathrm{~mm} \mathrm{Hg} /$ $s$ and from $829 \pm 94$ to $942 \pm 85 \mathrm{~mm} \mathrm{Hg} / \mathrm{s}$ (NS); increased (-) $\mathrm{dP} / \mathrm{dt}_{\max }$ from $883 \pm 73$ to $926 \pm 45 \mathrm{~mm} \mathrm{Hg} / \mathrm{s}$ and from $923 \pm 82$ to $1054 \pm 78 \mathrm{~mm} \mathrm{Hg} / \mathrm{s}$ (NS); and decreased perfusion pressure from $57.9 \pm 4.9$ to $50.0 \pm 3.6 \mathrm{~mm} \mathrm{Hg}$ and from $59.0 \pm 4.3$ to $44.6 \pm 3.8 \mathrm{~mm} \mathrm{Hg}$, respectively $(p$ $<0.05)$. Isoproterenol $(n=5,0.1$ and $0.5 \mathrm{nmol})$ increased (+) $\mathrm{dP} / \mathrm{dt}_{\max }$ from $793 \pm 51$ to $1343 \pm 75 \mathrm{~mm} \mathrm{Hg} / \mathrm{s}(p=$ $0.09)$ and from $825 \pm 38$ to $2275 \pm 275 \mathrm{~mm} \mathrm{Hg} / \mathrm{s}(p<$ 0.05 ); increased (-) $\mathrm{dP} / \mathrm{dt}_{\max }$ from $977 \pm 56$ to $1314 \pm 66$ $\mathrm{mm} \mathrm{Hg} / \mathrm{s}$ and from $865 \pm 35$ to $1738 \pm 143 \mathrm{~mm} \mathrm{Hg} / \mathrm{s}(p$ $<0.05$ ); and decreased perfusion pressure from $58.8 \pm 2.2$ to $51.6 \pm 2.3 \mathrm{~mm} \mathrm{Hg}$ and from $64 \pm 2.3$ to $49.8 \pm 2.9 \mathrm{~mm}$ $\mathrm{Hg}$, respectively $(p<0.05)$. In summary, PACAP produced positive inotropic, luisitropic, and coronary vasodilatory effects in piglet hearts, which may make PACAP a promising cardiotonic agent for the treatment of neonates with myocardial contractile dysfunction. (Pediatr Res 34: 323-328, 1993)
\end{abstract}

Received July 15, 1992; accepted April 23, 1993.

Correspondence and reprint requests: Nancy T. Ross-Ascuitto, M.D., Tulane University Medical Center, Department of Pediatrics, 1430 Tulane Ave., New Orleans, LA, 70112.

Supported in part by a grant from the National Institutes of Health (R29 HL 45603-01A1).

\section{Abbreviations}

PACAP, pituitary adenylate cyclase activating polypeptide VIP, vasoactive intestinal polypeptide

ISP, isoproterenol

IBMX, isobutylmethylxanthine

$\mathrm{dP} / \mathrm{dt}_{\max }$, maximum rate of change of systolic pressure with respect to time

$(+)$, positive

$(-)$, negative

PACAP is a newly discovered neuropeptide isolated from the ovine hypothalamus (1). PACAP is present in two forms: one with 27 and the other with $38 \mathrm{~N}$-terminal amino acid residues (2). PACAP has a $68 \%$ sequence homology with VIP and appears to be more potent than VIP in stimulating adenylate cyclase in pituitary cells (2). PACAP also has been shown to increase cAMP levels in the human neuroblastoma cell line NB-OK (3), the rat pancreatic acinar cell line AR 4-2J (4), and rat liver cell membranes (5). Moreover, high affinity binding sites for PACAP have been identified in several organ systems, including the rat lung (6) and human brain (7).

The physiologic role of PACAP has not been elucidated, although it has been suggested that this peptide may be involved in the regulation of vascular smooth muscle tone, in addition to its presumed role as a hypothalamic, hypophysiotropic hormone (8). Although binding sites for PACAP have been identified on large blood vessels, little is known about the biological effects of PACAP in vascular beds of intact organs (9). Recently, Minkes et al. (10) have shown that PACAP produces pulmonary vasodilation and can elicit both vasodilatory and vasoconstrictor responses in the hindlimb vasculature of cats.

Cardiac effects of PACAP have not been previously reported. Such information, however, is of importance because VIP-like immunoreactivity has been demonstrated in nerve fibers of hearts (11). Similarly, receptors for the homologous peptide, VIP, have been demonstrated in the myocardium and coronary arteries of several adult species (12). The present study, therefore, was undertaken to investigate the effects of PACAP on contractile function and coronary vascular tone using neonatal pig hearts. Isolated isovolumically beating hearts were perfused with an erythrocyte-enriched solution under conditions of constant coronary flow (approximately $3 \mathrm{~mL} \cdot \mathrm{min}^{-1} \cdot \mathrm{g}^{-1}$ wet heart weight). The cardiac effects of PACAP were compared with those obtained with VIP and the ISP. We chose to investigate PACAP in piglet hearts because we previously have shown that agents that increase cAMP in these neonatal hearts produce positive ino- 
tropic and coronary vasodilatory effects (13). Additionally, we studied PACAP in immature hearts because clinically a combination of inotropic support and afterload reduction through systemic vasodilatation frequently is beneficial in the treatment of neonates with myocardial contractile dysfunction.

\section{MATERIALS AND METHODS}

Preparation of erythrocytes and perfusate. The perfusate $\left(37^{\circ} \mathrm{C}\right)$ consisted of a crystalloid solution containing insulin $(200 \mu \mathrm{U} /$ $\mathrm{mL}$ ) and the following salts (in $\mathrm{mM}$ ): $\mathrm{NaCl}, 118 ; \mathrm{KCl}, 4.7$; $\mathrm{MgSO}_{4}, 2.4 ; \mathrm{KH}_{2} \mathrm{PO}_{4}, 1.2 ; \mathrm{NaHCO}_{3}, 25 ; \mathrm{CaCl}_{2}, 2.4$; glucose 5.5 $\mathrm{mM}$; and $2 \%$ BSA (BSA, Cohn Fraction V, U.S. Biochemical Corp., Cleveland, $\mathrm{OH}$ ). Out-dated saline-washed human erythrocytes (tested negative for hepatitis $B$ and human immunodeficiency virus) were then suspended in this solution (hematocrit 15 to $20 \%$ ) to provide physiologic oxygen delivery and buffering capacity for these large hearts $(12.0 \pm 0.9 \mathrm{~g})$. Using this isolated heart preparation, we have previously demonstrated that enrichment of a crystalloid perfusate with either human or pig erythrocytes results in similar levels of contractile function for piglet hearts (14). Therefore, in these experiments, banked human erythrocytes were used because of their ease of availability. The $\mathrm{pH}$ of the final solution was adjusted to $7.4-7.45$ by titration with $1 \mathrm{~N} \mathrm{NaOH}$. The lactate concentration of the final solution was 2 to $4 \mathrm{mM}$.

Preparation of isolated hearts. Pigs, 1 to $5 \mathrm{~d}$ of age, were used for these studies. Isolated isovolumically beating hearts were prepared as described previously (13-15). Briefly, piglets were anesthetized with sodium pentobarbital $(25 \mathrm{mg} / \mathrm{kg}$ intraperitoneal), anticoagulated with heparin sodium (1000 U/kg i.v.), and mechanically ventilated via a tracheostomy. After a sternotomy, the hearts were excised rapidly and immediately placed in icecold Krebs-Henseleit solution.

Using the modified Langendorff system described previously $(13-15)$ and depicted in Figure 1, hearts underwent retrograde aortic perfusion with the crystalloid solution for approximately $5 \mathrm{~min}$ to flush the coronary arteries of debris and then were perfused with the erythrocyte-enriched solution. The enhanced oxygen carrying capacity, provided by the erythrocytes, ensured that coronary flow rates could be kept near the physiologic range (16) without compromising contractile performance. Furthermore, coronary vascular tone would be maintained, and thus coronary vascular responsiveness could be studied during the experiment. Hence, responses to agonists were investigated without the necessity and additional complexity of using agents to predilate or precontract the coronary vasculature. Such agents also might adversely affect contractile function.

Hearts were allowed to equilibrate for approximately $15 \mathrm{~min}$ while being perfused at constant coronary perfusion pressure. After equilibration, hearts then underwent nonrecirculating perfusion at constant coronary flow $\left(2.7 \pm 0.3 \mathrm{~mL} \cdot \mathrm{min}^{-1} \mathrm{~g} \cdot{ }^{-1}\right.$ wet heart weight). In each experiment, the flow rate was chosen to produce a coronary perfusion pressure of approximately $60 \mathrm{~mm}$ $\mathrm{Hg}$, which is the in vivo aortic diastolic pressure measured in neonatal pigs (17). Perfusing hearts at constant coronary flow followed us to study responses to agonists without impairing oxygen delivery, which may have adversely affected contractile function. In this preparation, coronary venous return flows from the right atrium to the right ventricle and then is pumped into the pulmonary artery, which is cannulated with a nonrestrictive (3-mm diameter) tube. Thus, the right ventricle pumps only against atmospheric pressure. The right atrial pressure is therefore low and has a minimal effect on coronary perfusion pressure. We have confirmed this result by measuring right atrial pressure using a 4-French catheter that was inserted into the right atrium via the inferior vena cava. Typically during the experiment, mean right atrial pressure was found to be 1 to $2 \mathrm{~mm} \mathrm{Hg}$. Thus, changes in coronary perfusion pressure reflected alterations in

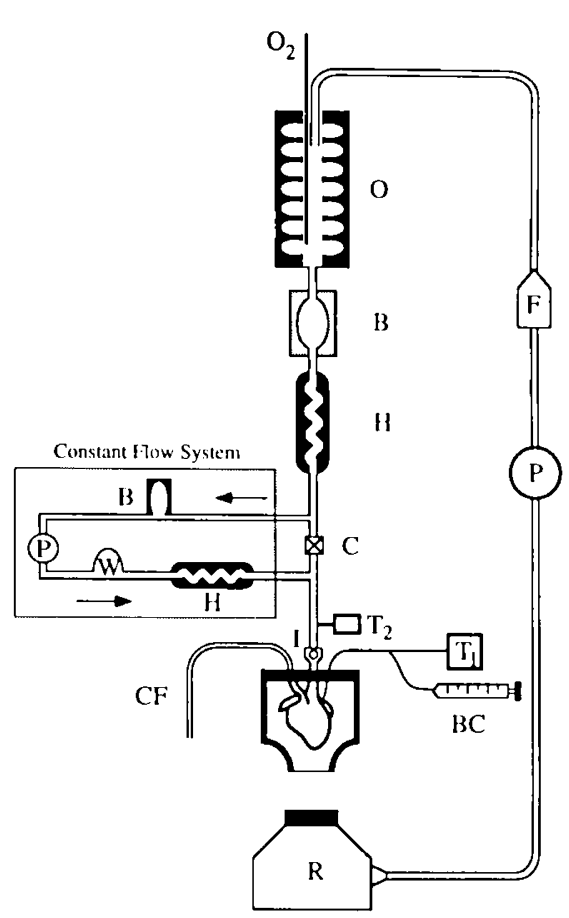

Fig. 1. Apparatus for isolated heart perfusion. Perfusate in reservoir $(R)$ was pumped through a filter $(F)$, an oxygenating column $(O)$, bubble trap $(B)$, and heating condenser $(H)$. Before entering the aorta, the perfusate passed through a constant-flow system containing a bubble trap $(B)$, calibrated pump $(P)$, which maintained the coronary flow at the desired constant value, a pulsatile flow damping chamber $(W)$, and a heating condenser $(H)$. Coronary perfusion was switched from constant perfusion pressure to constant flow using an adjustable clamp $(C)$. Myocardial temperature was kept at $37^{\circ} \mathrm{C}$ by enclosing the heart in a heated water jacket. Left ventricular isovolumic pressure was monitored by a pressure transducer $\left(T_{1}\right)$ attached to a fluid-filled balloon catheter $(B C)$ in the left ventricular chamber. Coronary perfusion pressure was monitored with a pressure transducer $\left(T_{2}\right)$ attached to a side port above the heart. Bolus injections of agonists were administered through an injection port $(I)$ just above the aortic cannula. Coronary venous return egressed from the pulmonary artery cannula $(C F)$. Coronary venous return was collected separately and not returned to the reservoir $(R)$.

vascular tone because right atrial pressure was low and coronary flow was held constant.

Left ventricular contractile function was assessed by isovolumic pressure generation and the $\mathrm{dP} / \mathrm{dt}_{\max }$, which were monitored via a 5 French fluid-filled balloon catheter in the ventricular chamber. Both $(+)$ and $(-) \mathrm{dP} / \mathrm{dt}_{\max }$ were determined, allowing an assessment of left ventricular inotropy and relaxation.

The left ventricular end-diastolic pressure was set at approximately $5 \mathrm{~mm} \mathrm{Hg}$, which is physiologic for a neonate, by adjusting the volume of fluid in the balloon. Once the end-diastolic pressure was set, the volume of fluid in the balloon was not changed. Therefore, changes in end-diastolic pressure reflected alterations in left ventricular compliance because coronary flow was held constant. Hearts were paced via the right ventricle at 180 beats/ min. The arterial perfusate oxygen content was maintained at approximately 7.5 to 8.0 vol \% (hematocrit approximately $15 \%$ and $\mathrm{PO}_{2}$ approximately 250 to $300 \mathrm{~mm} \mathrm{Hg}$ ) by passing a mixture of $95 \% \mathrm{O}_{2}: 5 \% \mathrm{CO}_{2}$ through the perfusate in the Langendorff column.

Preparation of solutions. PACAP (Peptide Laboratories, Tulane University School of Medicine, New Orleans, LA) and VIP (Peninsula Laboratories Inc., Belmont, CA) were dissolved in $0.9 \%$ sodium chloride. The homogeneity of the peptides was assessed by thin-layer chromatography and analytical reversephase, HPLC. The purity of the peptides was $97 \%$ or greater. Isoproterenol $\mathrm{HCl}$ (Winthrop Pharmaceutical, NY) was diluted 
with saline (1:10) before use. Propranolol $\mathrm{HCl}(1 \mathrm{mg} / \mathrm{mL})($ Smith \& Nephew) was used directly from the vial.

Experimental protocols. The first part of this study was designed to test the cardiac effects of PACAP in eight piglet hearts. PACAP, 0.1 and $0.5 \mathrm{nmol}$, was injected as a bolus over approximately $1 \mathrm{~s}$ into the aortic root of each heart. These doses of PACAP were chosen so $\mathrm{dP} / \mathrm{dt}_{\max }$ and vascular tone would return to near baseline levels on washout of the hormone. Similar doses of PACAP also have been shown to evoke vasoactive effects in the pulmonary and systemic (hindquarter) vascular beds of cats (10). In four of the experiments, the $0.1-\mathrm{nmol}$ dose of PACAP was administered first, followed by the $0.5-\mathrm{nmol}$ dose. In the remaining four experiments, the order of administration was reversed. PACAP was administered only after $\mathrm{dP} / \mathrm{dt}_{\max }$ and coronary perfusion pressure had returned to near baseline values and had stabilized. The effects of PACAP on $(+)$ and $(-) \mathrm{dP} /$ $\mathrm{dt}_{\max }$ (in $\mathrm{mm} \mathrm{Hg} / \mathrm{s}$ ) and coronary perfusion pressure (in $\mathrm{mm} \mathrm{Hg}$ ) were then determined.

As a comparison, the effects of ISP, 0.1 and $0.5 \mathrm{nmol}$, on (+) and $(-) \mathrm{dP} / \mathrm{dt}_{\max }$ and coronary perfusion pressure were studied in five hearts.

The second part of this study compared the effects of PACAP with VIP. In six additional hearts, VIP, 0.1 and $0.5 \mathrm{nmol}$, was studied in a method similar to that for PACAP. The changes in $(+)$ and $(-) \mathrm{dP} / \mathrm{dt}_{\max }$ and coronary perfusion pressure were then compared with the corresponding changes in these parameters obtained with PACAP. In another four hearts, VIP $(0.1 \mathrm{nmol})$ was administered, followed by a dose of PACAP $(0.1 \mathrm{nmol})$. PACAP was given approximately $30 \mathrm{~s}$ after VIP, when perfusion pressure had reached its nadir as a consequence of VIP. The same dose of PACAP was then administered approximately 10 min later. In each case, the effect of these agents on $(+) \mathrm{dP} / \mathrm{dt}_{\max }$ was determined. These experiments were performed to determine whether VIP might diminish the effect of PACAP on inotropy.

The third part of this study assessed whether the inotropic effect of PACAP could be potentiated by phosphodiesterase inhibition. An augmentation of PACAP's effect on $(+) \mathrm{dP} / \mathrm{dt}_{\max }$ by phosphodiesterase inhibition would support the premise that PACAP's inotropic action is mediated by an increase in cAMP. In the present study, we used the nonspecific phosphodiesterase inhibitor IBMX to study this effect because we have previously demonstrated that IBMX increases CAMP levels in isolated piglet myocytes (13). Thus, in four experiments, PACAP $(0.1 \mathrm{nmol})$ was given, and its effect on $(+) \mathrm{dP} / \mathrm{dt}_{\max }$ was determined. IBMX was then infused into the aortic root at a rate of 50 to $150 \mu \mathrm{g} /$ min, which produced an approximately $12 \%$ increase in $(+) \mathrm{dP} /$ $\mathrm{dt}_{\max }$. The hearts were then rechallenged with the same dose of PACAP, and the influence of IBMX on the inotropic response of PACAP was determined.

Data analysis. The results are presented as means \pm SEM. Analysis of variance or analysis of variance with repeated measures was used to analyze differences in the response to PACAP, VIP, and ISP. The least significant difference test was used to analyze differences among means. Differences among means were considered to be significant when $p<0.05$.

\section{RESULTS}

Influence of PACAP on contractile function and coronary perfusion pressure. PACAP produced a positive inotropic and lusitropic effect, as manifested by an increase in $(+) \mathrm{dP} / \mathrm{dt}_{\max }$ (Fig. $2 A)$ and $(-) \mathrm{dP} / \mathrm{dt}_{\max }$ (Fig. $2 B$ ). PACAP increased $(+) \mathrm{dP} / \mathrm{dt}_{\max }$ from $944 \pm 59$ to $1519 \pm 206 \mathrm{~mm} \mathrm{Hg} / \mathrm{s}$ and from $867 \pm 40$ to $2010 \pm 226 \mathrm{~mm} \mathrm{Hg} / \mathrm{s}$ for the $0.1-$ and 0.5 -nmol doses, respectively $(p<0.05)$. The mean percent increase in $(+) \mathrm{dP} / \mathrm{dt}_{\max }$ from baseline for the 0.5 -nmol dose $(129.6 \pm 18.5 \%)$ was significantly greater than that for the $0.1-\mathrm{nmol}$ dose $(57.0 \pm 11.6 \%$; $p<0.05)$. Similarly, PACAP increased $(-) \mathrm{dP} / \mathrm{dt}_{\max }$ from 1114 \pm 41 to $1439 \pm 95 \mathrm{~mm} \mathrm{Hg} / \mathrm{s}$ and from $999 \pm 37$ to $1668 \pm 145$ $\mathrm{mm} \mathrm{Hg} / \mathrm{s}$ for the $0.1-$ and $0.5-\mathrm{nmol}$ doses, respectively $(p<$
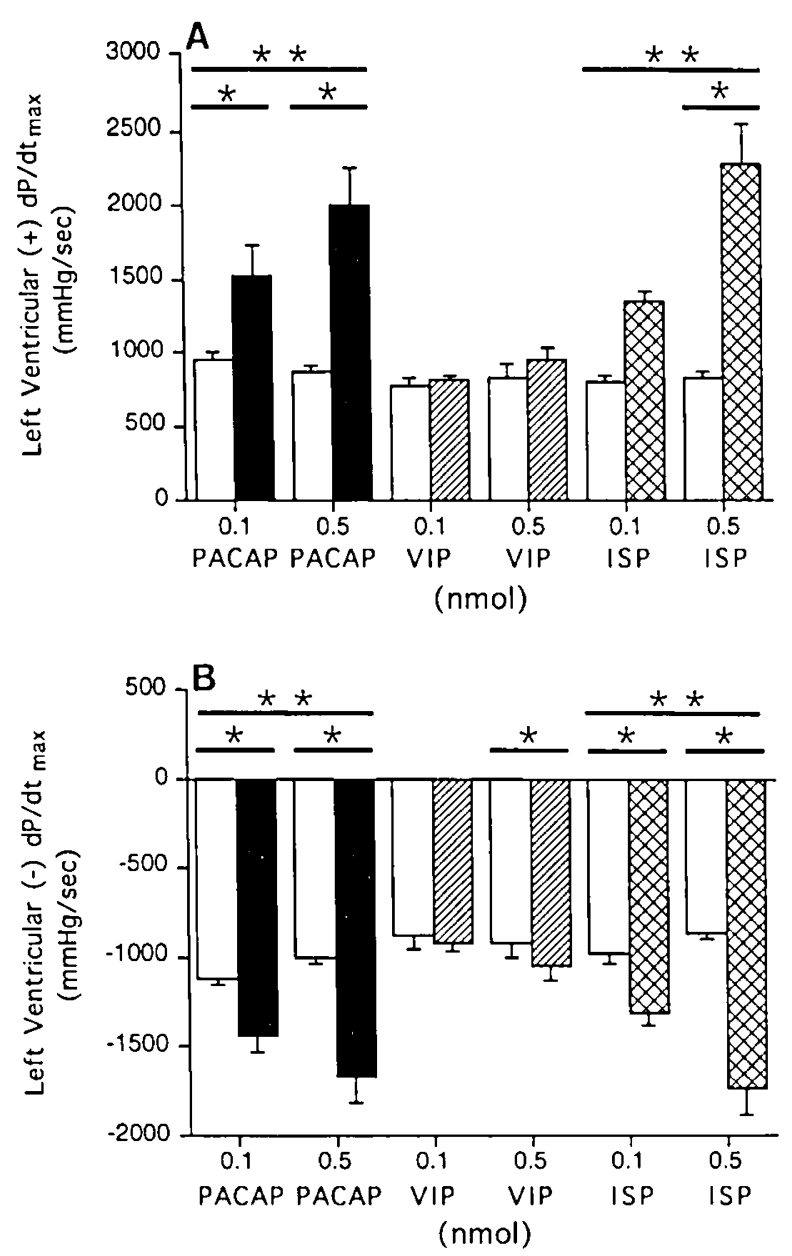

Fig. 2. $A$, Effects of agonists on $(+) \mathrm{dP} / \mathrm{dt}_{\max }$. Left ventricular $(+) \mathrm{dP} /$ $\mathrm{dt}_{\max }$ in $\mathrm{mm} \mathrm{Hg} / \mathrm{s}$ under baseline conditions ( $\square$ ), i.e. just before the addition of each agonist, and in response to PACAP ( $\square, 0.1$ and 0.5 $\mathrm{nmol}$ ), VIP (G, 0.1 and $0.5 \mathrm{nmol}$ ), and ISP ( results are expressed as mean \pm SEM. Single asterisks above horizontal lines indicate statistically significant differences from baseline. Double asterisks above horizontal lines indicate statistically significant differences between the responses for the $0.1-$ and $0.5-\mathrm{nmol}$ doses. $B$, Effects of agonists on $(-) \mathrm{dP} / \mathrm{dt}_{\max }$. Left ventricular $(-) \mathrm{dP} / \mathrm{dt}_{\max }$ in $\mathrm{mm} \mathrm{Hg} / \mathrm{s}$ under baseline conditions $(\square)$, i.e. just before the addition of each agonist, and in response to $\operatorname{PACAP}(\square, 0.1$ and $0.5 \mathrm{nmol}), \mathrm{VIP}(\mathrm{D}, 0.1$ and 0.5 $\mathrm{nmol}$ ), and ISP ( $\mathrm{H}, 0.1$ and $0.5 \mathrm{nmol}$ ). The results are expressed as mean \pm SEM. Single asterisks above horizontal lines indicate statistically significant differences from baseline. Double asterisks above horizontal lines indicate statistically significant differences between the responses for the 0.1 - and $0.5-\mathrm{nmol}$ doses.

$0.05)$. PACAP also produced coronary vasodilatation as reflected by a decrease in coronary perfusion pressure (Fig. 3). PACAP decreased perfusion pressure from $61.4 \pm 3.1$ to $48.9 \pm 2.3 \mathrm{~mm}$ $\mathrm{Hg}$ and from $60.5 \pm 2.4$ to $43.9 \pm 2.3 \mathrm{~mm} \mathrm{Hg}$ for the $0.1-$ and $0.5-\mathrm{nmol}$ doses, respectively $(p<0.05)$. The mean percent decrease in perfusion pressure from baseline for the $0.5-\mathrm{nmol}$ dose $(27.4 \pm 2.5 \%)$ did not strictly achieve statistical significance $(p=0.07)$ when compared with the $0.1-\mathrm{nmol}$ dose $(19.8 \pm 2.8 \%$; $p<0.05)$. The peak change in $(+) \mathrm{dP} / \mathrm{dt}_{\max }$ and perfusion pressure occurred within approximately 1 to $2 \mathrm{~min}$ after administration of PACAP. The $(+) \mathrm{dP} / \mathrm{dt}_{\max }$ returned to near baseline values within approximately $5 \mathrm{~min}$; however, perfusion pressure tended to remain below baseline, in some experiments, for at least $15 \mathrm{~min}$.

In the four hearts in which the $0.5-\mathrm{nmol}$ dose of PACAP was administered before the $0.1-\mathrm{nmol}$ dose, the absolute increase in (+) $\mathrm{dP} / \mathrm{dt}_{\max }$ for the $0.1-\mathrm{nmol}$ dose was $360 \pm 110 \mathrm{~mm} \mathrm{Hg} / \mathrm{s}$. In 


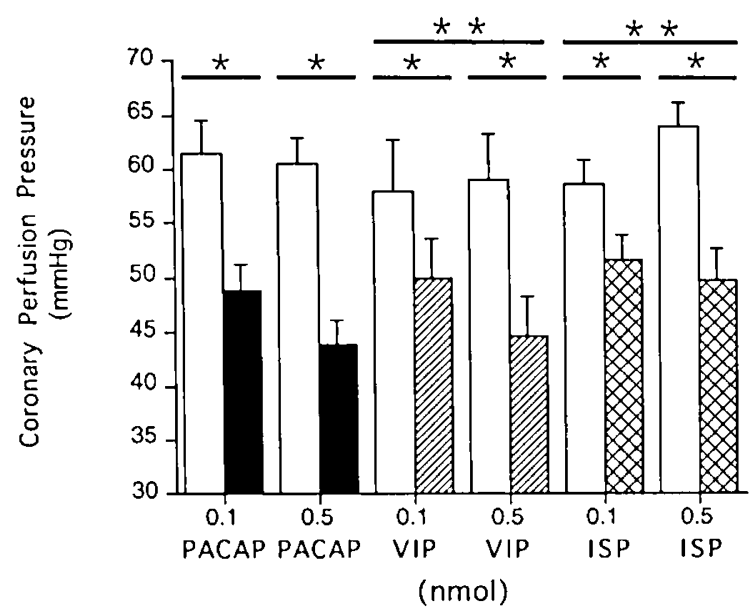

Fig. 3. Effects of agonists on coronary perfusion pressure. Coronary perfusion pressure in $\mathrm{mm} \mathrm{Hg}$ under baseline conditions ( $\square$ ), i.e. just before the addition of each agonist, and in response to PACAP $(\boldsymbol{\square}, 0.1$ and $0.5 \mathrm{nmol}), \operatorname{VIP}(\mathrm{B}, 0.1$ and $0.5 \mathrm{nmol})$, and ISP ( $\mathrm{H}, 0.1$ and 0.5 $\mathrm{nmol})$. The results are expressed as mean \pm SEM. Single asterisks above horizontal lines indicate statistically significant differences from baseline. Double asterisks above horizontal lines indicate statistically significant differences between the responses for the $0.1-$ and $0.5-\mathrm{nmol}$ doses.

contrast, in the four hearts in which the $0.1-\mathrm{nmol}$ dose of PACAP was administered first, the increase in $(+) \mathrm{dP} / \mathrm{dt}_{\max }$ for the 0.1 nmol dose was $791 \pm 261 \mathrm{~mm} \mathrm{Hg} / \mathrm{s}$. However, when the 0.1 $\mathrm{nmol}$ dose was given first, the $0.1-\mathrm{nmol}$ dose did not significantly diminish the response to the 0.5 -nmol dose. These results demonstrate that a large dose of PACAP can attenuate the inotropic response to a lower dose administered later.

In four additional experiments, hearts were also treated with propranolol (100 nmol) before the administration of PACAP to determine whether the effects of PACAP were altered by $\beta$ adrenergic receptor blockade. This dose of propranolol was found to abolish, for example, the inotropic effect of $0.1 \mathrm{nmol}$ of ISP (see below). Pretreatment with propranolol, however, had no significant effect on the inotropic response with PACAP.

Influence of ISP on contractile function and coronary perfusion pressure. The effects of ISP on $(+) \mathrm{dP} / \mathrm{dt}_{\max },(-) \mathrm{dP} / \mathrm{dt}_{\max }$, and coronary perfusion pressure are also shown in Figures $2 A, 2 B$ and 3 , respectively. ISP increased $(+) \mathrm{dP} / \mathrm{dt}_{\max }$ from $793 \pm 51$ to $1343 \pm 75 \mathrm{~mm} \mathrm{Hg} / \mathrm{s}$ and from $825 \pm 38$ to $2275 \pm 275 \mathrm{~mm}$ $\mathrm{Hg} / \mathrm{s}$ for the $0.1-$ and $0.5-\mathrm{nmol}$ doses, respectively. The increase in $(+) \mathrm{dP} / \mathrm{dt}_{\max }$ for the $0.1-\mathrm{nmol}$ dose did not strictly achieve statistical significance $(p=0.09)$. ISP also increased $(-) \mathrm{dP} / \mathrm{dt}_{\max }$ from $977 \pm 56$ to $1314 \pm 66 \mathrm{~mm} \mathrm{Hg} / \mathrm{s}$ and from $865 \pm 35$ to $1738 \pm 143 \mathrm{~mm} \mathrm{Hg} / \mathrm{s}$ for the $0.1-$ and $0.5-\mathrm{nmol}$ doses, respectively $(p<0.05)$. Coronary perfusion pressure decreased from $58.8 \pm 2.2$ to $51.6 \pm 2.3 \mathrm{~mm} \mathrm{Hg}$ and from $64.0 \pm 2.3$ to $49.8 \pm$ $2.9 \mathrm{~mm} \mathrm{Hg}$ for the $0.1-$ and $0.5-\mathrm{nmol}$ doses, respectively $(p<$ 0.05 ). The mean percent decrease in perfusion pressure from baseline for the $0.5-\mathrm{nmol}$ dose $(22.3 \pm 2.3 \%)$ was significantly greater than for the $0.1-\mathrm{nmol}$ dose $(12.3 \pm 1.1 \% ; p<0.05)$. Additionally, the mean percent decrease in perfusion pressure from baseline for the $0.1-\mathrm{nmol}$ dose of ISP was less than the corresponding response for PACAP $(p<0.05)$. The percent decrease from baseline for the $0.5-\mathrm{nmol}$ dose of ISP, however, was comparable to that for PACAP.

Influence of VIP on contractile function and coronary perfusion pressure. VIP increased $(+) \mathrm{dP} / \mathrm{dt}_{\max }$ from $767 \pm 53$ to $806 \pm 37$ $\mathrm{mm} \mathrm{Hg} / \mathrm{s}$ and from $829 \pm 94$ to $942 \pm 85 \mathrm{~mm} \mathrm{Hg} / \mathrm{s}$ for the $0.1-$ and $0.5-\mathrm{nmol}$ doses, respectively (Fig. $2 A$ ). The mean percent increases in $(+) \mathrm{dP} / \mathrm{dt}_{\max }$ from baseline $(6.8 \pm 5.5 \%$ and $16.4 \pm$ $8.9 \%)$ were not statistically significant. VIP increased $(-) \mathrm{dP} /$ $\mathrm{dt}_{\max }$ from $883 \pm 73$ to $926 \pm 45 \mathrm{~mm} \mathrm{Hg} / \mathrm{s}$ and from $923 \pm 82$ to $1054 \pm 78 \mathrm{~mm} \mathrm{Hg} / \mathrm{s}$, respectively. Similarly, the percent increases in (-) $\mathrm{dP} / \mathrm{dt}_{\max }$ from baseline were not statistically significant. However, VIP decreased coronary perfusion pressure from $57.9 \pm 4.9$ to $50.0 \pm 3.6 \mathrm{~mm} \mathrm{Hg}$ and from $59.0 \pm 4.3$ to $44.6 \pm 3.8 \mathrm{~mm} \mathrm{Hg}$ for the $0.1-$ and $0.5-\mathrm{nmol}$ doses, respectively $(p<0.05$; Fig. 3). The mean percent decrease in perfusion pressure from baseline for the 0.5 -nmol dose $(24.4 \pm 2.6 \%)$ was significantly more than that for the $0.1-\mathrm{nmol}$ dose $(13.1 \pm 1.8 \%$; $p<0.05$ ). The percent decrease in perfusion pressure from baseline for the 0.1-nmol dose of VIP was less than that for PACAP, although this did not strictly achieve statistical significance $(p=0.05)$. The percent decrease in perfusion pressure for the 0.5 -nmol dose of VIP was not statistically different from that for PACAP.

Influence of VIP on PACAP's inotropic response. In four hearts, administration of VIP $(0.1 \mathrm{nmol})$ before a bolus injection of PACAP $(0.1 \mathrm{nmol})$ significantly reduced PACAP's effect on $(+)$ $\mathrm{dP} / \mathrm{dt}_{\max }$. PACAP increased $(+) \mathrm{dP} / \mathrm{dt}_{\max }$ only $230 \pm 76 \mathrm{~mm} \mathrm{Hg} /$ $s$ directly after VIP, whereas $10 \mathrm{~min}$ later the same dose of PACAP increased $(+) \mathrm{dP} / \mathrm{dt}_{\max } 468 \pm 65 \mathrm{~mm} \mathrm{Hg} / \mathrm{s}(p<0.05$, Fig. 4). The response to PACAP directly after VIP (230 \pm 76 $\mathrm{mm} \mathrm{Hg} / \mathrm{s}$ ) also should be compared with the absolute increase of $791 \pm 261 \mathrm{~mm} \mathrm{Hg} / \mathrm{s}$, which occurred in the four hearts described above when PACAP was administered first in the experiment and in the absence of VIP $(p<0.05$, Fig. 4).

Influence of phosphodiesterase inhibition on PACAP's inotropic response. In four hearts when PACAP was administered in the presence of an IBMX infusion, $(+) \mathrm{dP} / \mathrm{dt}_{\max }$ increased $934 \pm 136$ $\mathrm{mm} \mathrm{Hg} / \mathrm{s}$, whereas before the IBMX infusion, PACAP increased (+) $\mathrm{dP} / \mathrm{dt}_{\max }$ by $426 \pm 90 \mathrm{~mm} \mathrm{Hg} / \mathrm{s}$ (Fig. 5). Thus, IBMX augmented the effect of PACAP on $(+) \mathrm{dP} / \mathrm{dt}_{\max }$ by $132 \pm 24 \%$ $(p<0.05)$.

\section{DISCUSSION}

The present investigation demonstrates that PACAP produces positive inotropic and lusitropic effects in isolated neonatal pig hearts. PACAP's inotropic effect was manifested by an approximately $60 \%$ and approximately $130 \%$ increase in $(+) \mathrm{dP} / \mathrm{dt}_{\max }$ at doses of 0.1 and $0.5 \mathrm{nmol}$, respectively. The percent changes in $(+) \mathrm{dP} / \mathrm{dt}_{\max }$ were comparable to those produced by ISP.

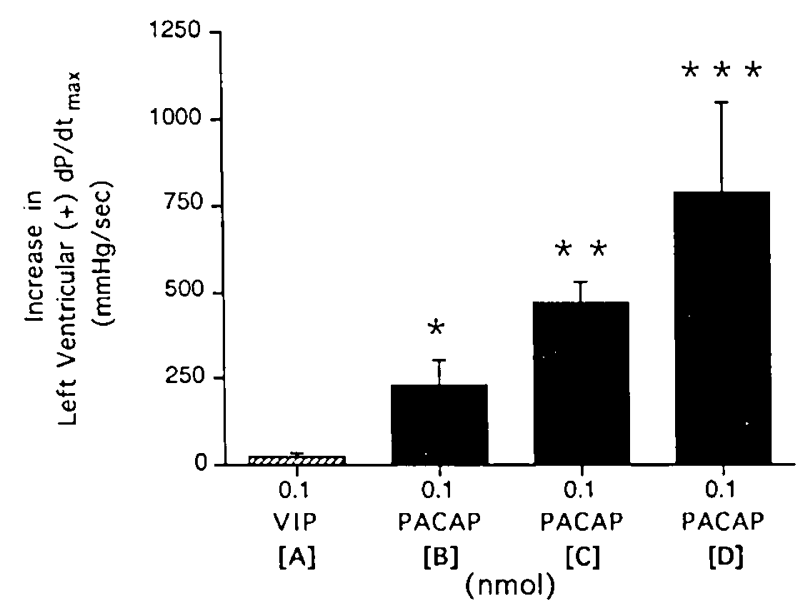

Fig. 4. Influence of VIP on PACAP's effect on $(+) \mathrm{dP} / \mathrm{dt}_{\max }$. [A] . increase in left ventricular $(+) \mathrm{dP} / \mathrm{dt}_{\max }$ from baseline in $\mathrm{mm} \mathrm{Hg} / \mathrm{s}$ in response to VIP $(\mathrm{Q}, 0.1 \mathrm{nmol}) ;[B]$, increase in left ventricular $(+) \mathrm{dP} /$ $\mathrm{dt}_{\max }$ in $\mathrm{mm} \mathrm{Hg} / \mathrm{s}$ in response to PACAP (ם, $0.1 \mathrm{nmol}$ ) given approximately $30 \mathrm{~s}$ after the bolus injection of VIP; and $[C]$, in response to PACAP $(0.1 \mathrm{nmol})$, given $10 \mathrm{~min}$ after the VIP. $[D]$, response to PACAP $(0.1 \mathrm{nmol})$ in the four hearts where PACAP was administered in the absence of VIP. Single asterisk indicates a statistically significant difference between $[B]$ and $[A]$. Dotuble asterisk indicates a statistically significant difference between $[C]$ and $[B]$. Triple asterisk indicates a statistically significant difference between $[D]$ and $[B]$. 


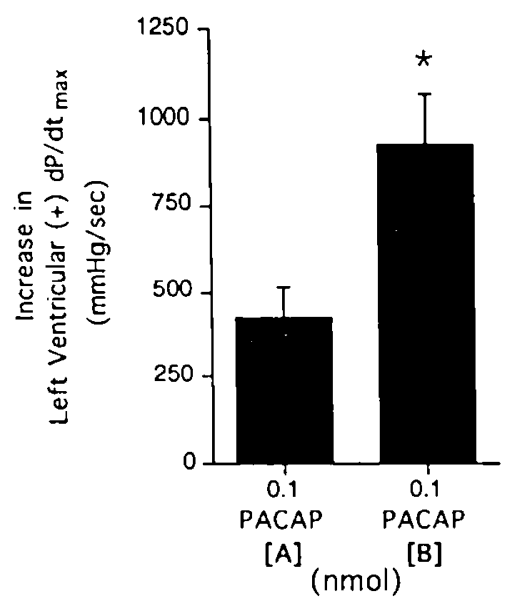

Fig. 5. Influence of IBMX on PACAP's effect on $(+) \mathrm{dP} / \mathrm{dt}_{\max } \cdot[\mathrm{A}]$, increase in left ventricular $(+) \mathrm{dP} / \mathrm{dt}_{\max }$ from baseline in $\mathrm{mm} \mathrm{Hg} / \mathrm{s}$ in response to PACAP $(\boldsymbol{\square}, 0.1 \mathrm{nmol})$; and $[B]$ in response to PACAP (ם. $0.1 \mathrm{nmol}$ ) administered in the presence of an IBMX infusion (50 to 150 $\mu \mathrm{g} / \mathrm{min})$. Asterisk indicates a statistically significant difference between $[B]$ and $[A]$.

However, the inotropic effect of PACAP was not significantly diminished by $\beta$-receptor blockade with propranolol. These results indicate that PACAP interacts with the piglet myocyte through a non- $\beta$-adrenergic receptor mediated mechanism. In support of this finding, recent investigations have demonstrated the presence of specific PACAP receptors in other tissues (18). PACAP's lusitropic effect was evident by an approximately $30 \%$ and $65 \%$ increase in $(-) \mathrm{dP} / \mathrm{dt}_{\max }$ at the $0.1-$ and $0.5-\mathrm{nmol}$ doses, respectively.

VIP was found to produce statistically insignificant increases in $(+)$ and $(-) \mathrm{dP} / \mathrm{dt}_{\max }$ when compared with PACAP. The weak inotropic effect of VIP at the doses studied is consistent with the work of Anderson et al. (19) who showed that injections of VIP into the left coronary artery of in vivo adult dog hearts produced substantial increases in $(+) \mathrm{dP} / \mathrm{dt}_{\max }$ only at doses in excess of approximately $0.7 \mathrm{nmol}$. However, when VIP was administered before a dose of PACAP, PACAP's effect on $(+) \mathrm{dP} / \mathrm{dt}_{\max }$ was still significant but markedly diminished compared with the response obtained when PACAP was given in the absence of VIP (Fig. 4). This result suggests that VIP may bind to a PACAP receptor on the myocyte to diminish PACAP's inotropic action. These findings support the speculation that PACAP and VIP may bind to a common receptor, although the mechanisms responsible for the inotropic response may differ for the two peptides. Additionally, we have found that phosphodiesterase inhibition augments PACAP's inotropic response (Fig. 5), which is consistent with a process involving increases in intracellular levels of cAMP.

Another important finding in this study was that PACAP produces coronary vasodilation, as reflected by significant decreases in coronary perfusion pressure. The decreases in coronary perfusion pressure, observed with PACAP, were comparable to those produced by ISP. The vasodilatory effect of PACAP is consistent with the results of in vitro studies where PACAP produced relaxation of isolated rabbit aorta (9) and in vivo studies where PACAP was found to decrease systemic arterial blood pressure in the rat (20). VIP produced decreases in coronary perfusion pressure that were comparable to those observed with PACAP. Coronary vasodilatory effects of VIP also have been documented by other investigators (21). The vasodilatory responses we observed with PACAP in the coronary vasculature of the neonatal pig heart differ from the responses in the hindlimb of the cat where PACAP was found to be 3- to 10-fold less potent than VIP in dilating the hindlimb vasculature; and both PACAP and VIP were less potent than ISP (10). In our study, we found PACAP's coronary vasodilatory response to be at least compa- rable to that of ISP. The mechanism underlying the vasodilatory effect of PACAP (or VIP) on coronary vascular smooth muscle, however, has not been delineated. For example, in cerebral vessels of cats, VIP-induced vasodilation is not dependent on the release of endothelial-derived relaxing factor and is associated with increased levels of cAMP rather than CGMP (22). To our knowledge, similar studies have not been conducted for PACAP. It is also possible that PACAP exerts its dilatory effect on vascular smooth muscle through inhibition of intracellular calcium release, as has been suggested for VIP (23).

In conclusion, the present study demonstrates for the first time that PACAP, a recently discovered hypothalamic peptide structurally related to VIP, produces potent cardiac inotropic, lusitropic, and vasodilatory effects. A physiologic role for PACAP in the regulation of myocardial contractility, coronary vascular tone, or both, however, remains to be delineated. Of clinical relevance is the fact that PACAP has positive inotropic and coronary vasodilatory effects in neonatal pig hearts comparable to those of ISP. Thus, this neuropeptide may be a useful cardiotonic agent for the treatment of immature hearts with myocardial contractile dysfunction.

\section{REFERENCES}

1. Miyata A, Arimura A, Dahl R, Minamino N, Uehara A, Jiang L, Culler MD, Coy DH 1989 Isolation of a novel 38 residue-hypothalamic polypeptide which stimulates adenylate cyclase in pituitary cells. Biochem Biophys Res Commun 164:567-574

2. Miyata A, Jiang L, Dahl R, Kitada C. Kubo K. Fujino M, Minamino N. Arimura A 1990 Isolation of a neuropeptide corresponding to the $\mathrm{N}$-terminal 27 residues of the pituitary adenylate cyclase activating polypeptide with 38 residues (PACAP 38). Biochem Biophys Res Commun 170:643-648

3. Cauvin A. Buscail L. Gourlet P 1990 The novel VIP-like hypothalamic polypeptide PACAP interacts with high affinity receptors in the human neuroblastoma cell line NB-OK. Peptides 11:773-777

4. Buscail L. Gourlet P. Cauvin A 1990 Presence of highly selective receptors for PACAP (pituitary adenylate cyclase activating peptide) in membranes from the rat pancreatic acinar cell line AR 4-2J. FEBS J 262:77-81

5. Robberecht $P$, Gourlet $P$, Cauvin A. Buscail L, DeNeef P, Arimura A. Christophe J 1991 PACAP and VIP receptors in rat liver membranes. Am J Physiol 260:G97-G102

6. Lam H-C. Takahashi T, Ghatei MA. Kanse SM, Polak JM, Bloom SR 1990 Binding sites of a novel neuropeptide pituitary-adenylate-cyclase-activating polypeptide in the rat brain and lung. Eur J Biochem 193:725-729

7. Suda K, Smith DM, Ghatei MA, Murphy JK. Bloom SR 1991 Investigation and characterization of receptors for pituitary adenylate cyclase-activating polypeptide in human brain by radioligand binding and chemical crosslinking. J Clin Endocrinol Metab 72:958-964

8. Koves K, Arimura A. Somogyvari-Vigh A. Vigh S, Miller J 1990 Immunohistochemical demonstration of a novel hypothalamic peptide, pituitary adenylate cyclase-activating polypeptide, in the ovine hypothalamus. Endocrinology 127:264-271

9. Warren JB, Donnelly LE, Cullen S, Robertson BE, Ghatei MA. Bloom SR, MacDermot J 1991 Pituitary adenylate cyclase-activating polypeptide: a novel, long-lasting, endothelium-independent vasorelaxant. Eur J Pharmacol 197:131-134

10. Minkes RK, McMahon TJ, Hood JS, Murphy WA, Coy DH, McNamara DB, Kadowitz PJ 1992 Differential effects of PACAP and VIP on the pulmonary and hindquarters vascular beds of the cat. J Appl Physiol 72:212-217

11. Della NG, Papka RE, Furness JB, Costa M 1983 Vasoactive intestinal peptidelike immunoreactivity in nerves associated with the cardiovascular system of pigs. Neuroscience 9:605-619

12. Huang M, Rorstad OP 1987 VIP receptors in mesenteric and coronary arteries: a radioligand binding study. Peptides 8:477-485

13. Ross-Ascuitto NT. Ascuitto RJ, Ramage D, McDonough KH 1991 The effects of milrinone in the neonatal pig heart. Cardiovasc Drugs Ther 5:1011-1019

14. Ross-Ascuitto NT, Ascuitto RJ, Chen V, Downing SE 1987 Negative inotropic effects of amrinone in the neonatal piglet heart. Circ Res 61:847-852

15. Ascuitto RJ, Ross-Ascuitto NT, Chen V. Downing SE 1989 Ventricular function and fatty acid metabolism in the neonatal piglet heart. Am J Physiol 256:H9-H15

16. Liedtke AJ, Hughes HC, Neely JR 1975 Metabolic responses to varying restrictions of coronary blood flow in swine. Am J Physiol 228:655-662

17. Werner JC, Whitman V, Fripp RR, Schuler HG, Morgan HE 1981 Carbohydrate metabolism in isolated, working newborn pig heart. Am J Physiol 241:E364-E371

18. Gottschall PE, Tatsuno I, Miyata A, Arimura A 1990 Characterization and distribution of binding sites for the hypothalamic peptide, pituitary adenylate cyclase activating polypeptide. Endocrinology 127:272-277 
19. Anderson FL, Kralios KC, Hershberger R, Bristow MR 1988 Effect of vasoactive intestinal peptide on myocardial contractility and coronary blood flow in the dog: comparison with isoproterenol and forskolin. J Cardiovase Pharmacol 12:365-371

20. Nandha KA, Bento-Orfila MA, Smith DM, Ghatei MA, Bloom SR 1991 Action of pituitary adenylate cyclase-activating polypeptide and vasoactive intestinal polypeptide on the rat vascular system: effect on blood pressure and receptor binding. J Endocrinol 129:69-73

21. Smitherman TL, Sakio H, Geumei AM, Yoshida T, Oyanmada M, Said S
1982 Coronary vasodilator action of VIP. In: Said SI (ed) Vasoactive Intestinal Peptide. Raven Press, New York, pp 169-176

22. Edvinsson L, Fredholm BB, Hamel E, Jansen I. Verreckhia C 1985 Perivascular peptides relax cerebral arteries concomitant with stimulation of cyclic adenosine monophosphate accumulation or release of an endothelium-derived relaxing factor in the cat. Neurosci Lett 58:213-217

23. Itoh I, Sasaguri T, Makita Y, Kanamura Y, Kuriyama H 1985 Mechanisms of vasodilation induced by vasoactive intestinal polypeptide in rabbit mesenteric artery. Am J Physiol 249:H231-H240 